
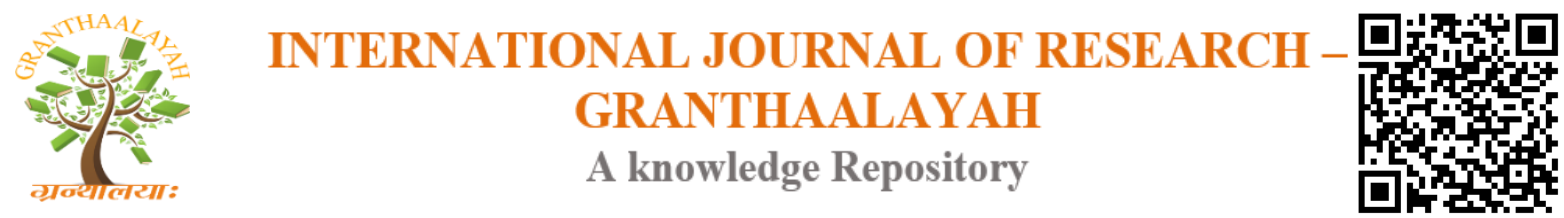

Science

\title{
EVALUATION OF NUTRITIONAL EFFECTS AND DIGESTIVE BALANCE OF THREE CASSAVA-DISHES COMMONLY CONSUMED IN CÔTE D'IVOIRE AT WISTAR RATS
}

\author{
Yéboué Kouamé Hermann ${ }^{1}$, Amoikon Kouakou Ernest ${ }^{1}$, Kouamé Konan Joël ${ }^{1}$, Zoho Bi \\ Foua Guy Alexendre ${ }^{1}$, Essé Sonia Estelle ${ }^{1}$ \\ ${ }^{1}$ Laboratory of Nutrition and Pharmacology, UFR Biosciences, Felix HOUPHOUËT-BOIGNY \\ University, Abidjan (Côte d'Ivoire)
}

\begin{abstract}
Valuing local dishes can help eradicate undernourishment in west Africa. In this context, the aim of this study is to evaluate in wistar rat nutritional effects and digestive balance of attiéké, attoukpou and placali, three cassava-dishes, commonly consumed in Côte d'Ivoire. For this purpose, 5 diets were composed to conduct growth and digestive balance experiments in wistar rats. Staple foods of the five diets are cassava-based foods (attiéké, attoukpou and placali), potatoes starch and sucrose. Four diets contain $45 \%$ of starch from different foods (attiéké, attoukpou, placali and potato). The last diet is starch-free, and contains sucrose as source of carbohydrate. This study showed that, cassava based-diets (attiéké, attoukpou and placali) have resulted in very good growth of rats, the efficiency of these foods is better, starch of cassava dishes has a digestibility greater than $95 \%$. However, because of the difference in culinary treatments, nutritional performance of attiéké is reduced compared to attoukpou and placali. Cassava-based foods, mainly attoukpou and placali, favored protein utilization in rat growth. Diets based on potato starch and sucrose have the lowest feed efficiency and a very low growth performance in rats. Consumption of Cassava dishes may therefore dampen undernourishment.
\end{abstract}

Keywords: Cassava-Dishes; Starch; Potato; Sucrose; Nutritional Effects; Digestibility; Wistar Rat.

Cite This Article: Yéboué Kouamé Hermann, Amoikon Kouakou Ernest, Kouamé Konan Joël, Zoho Bi Foua Guy Alexendre, and Essé Sonia Estelle. (2018). "EVALUATION OF NUTRITIONAL EFFECTS AND DIGESTIVE BALANCE OF THREE CASSAVA-DISHES COMMONLY CONSUMED IN CÔTE D'IVOIRE AT WISTAR RATS.” International Journal of Research - Granthaalayah, 6(11), 50-58. 10.29121/granthaalayah.v6.i11.2018.1088.

\section{Introduction}

Undernourishment remains a scourge in Africa. The number of undernourished people in West Africa from 2014 to 2016 is estimated at 31.5 million (FAO, 2015). West Africa is facing rapid population growth that is undermining countries' ability to ensure a stable supply of food and access to food. And yet, there is large production of dishes prepared with local tubers, such as 
cassava (FAO, 2015). Cassava is the main tuber grown worldwide with a global production of 257 million tons in 2012 (FAO, 2013) with 146 million tons from Africa (FAO, 2013). This tuber is the second food crop in Côte d'Ivoire, with production of 4.54 million tons in 2016 (APA, 2017). There are multiple dishes based on cassava (Perrin et al., 2015 Yao et al., 2015) whose rational consumption may eventually dampen undernourishment. In Côte d'Ivoire, attiéké, attoukpou and placali, are three dishes based on cassava well known (Yéboué et al., 2017). However, there is insufficient scientific information about nutritional impact of cassava-based foods and their digestibility in organisms. And yet, these dishes very rich in starch, could constitute a good nutritional potential in the fight against undernourishment. This study consists of evaluating the nutritional potential of three cassava-based dishes (attiéké, attoukpou and placali) commonly consumed in Côte d'Ivoire.

\section{Material and Methods}

\subsection{Material}

Plant material used for this work is cassava (Manihot esculenta Crantz) of variety IAC. This tuber has been used to prepare attiéké, attoukpou and placali. Experiment have focused on 35 growing rats, with an average weight of $61.82 \pm 0.20 \mathrm{~g}$. Rats were 65 days old.

Technical equipment consists of metabolic cages, precision laboratory balance (1/1000 g) used to determine weights, and drying oven (MMM Medcenter GmbH, D-82152, Munich Germany).

\subsection{Methods}

\section{Experimental Conditions}

Experiments have been performed in wistar rats from laboratory of Biosciences. Temperature of the animal house is $27^{\circ} \mathrm{C}$, room humidity is $80 \%$, with 12 hours of daylight and 12 hours of darkness. After weaning, animals are fed with pellets made by "IVOGRAIN" (Abidjan). Rats are allocated individually by cage, and receive ad libitum mixed semi-synthetic diets (Garcin et al., 1984), and water. From five prior to the start of experiment, rats were fed a soybean based diet, in order to become accustomed to experimental semi-synthetic diets.

\section{Composition and Preparation of Diets}

Isoproteic diets are prepared according to Garcin et al. (1984) with modifications. All diets were formulated to contain $18 \%$ protein, $45 \%$ starch and $5 \%$ lipid. Source of starch differs for individual diet. Predominantly composed of starch, cassava-based food (attiéké, attoukpou and placali) are incorporated into diets as source of starch. Starch of control diet is potato starch. Only one diet did not receive starch, which have been substitute by sugar (sucrose). Sunflower oil is the source of fat, and soya meal delipidated is the source of protein of each diet formulated. Supplement of vitamin and minerals was added at the rate of $10 \mathrm{~g}$ per $\mathrm{kg}$ of food (Laboratoire Boivé, France). Finally, distilled water has been used in preparing diets. Mixture of ingredients gives a compact mass, which will be administered to rats.

Dishes made from cassava come from Bonoua, in the south of Côte d'Ivoire, and sent to laboratory for drying, crushing and incorporation into diets. In total, five diets were formulated: 
- An experimental diet containing $45 \%$ of starch produced from attiéké powder (ATT);

- An experimental diet containing $45 \%$ of starch produced from attoukpou powder (ATO);

- An experimental diet containing $45 \%$ of starch produced from placali powder (PLA);

- A control diet containing 45\% starch produced from potato starch (POM);

- A starch-free diet has also been prepared with sugar (sugar is the diet's only source of carbohydrates).

\section{Growth and Digestive Balance Experience}

35 individually housed growing rats were used for experiment at 7 rats per diet. Growth experience lasted 15 days. Every morning, between $7 \mathrm{am}$ and $8 \mathrm{am}$, rats are fed and drinking water is renewed. For each diet, food is weighed and given individually to each rat. The next day, food remains are also weighed to determine amount of food ingested. Every three days, animals are weighed to estimate change in body weight.

Digestive balance study took place the last five days of experimentation according to Pellett \& Young (1980). During this experiment, food served, leftover food, and faeces excreted are weighed for each rat. At the end of the experiment, Starch and protein levels were determined in the foods served and feces excreted.

\section{Expression of Parameters of Nutritional Value and Digestive Balance of Food}

Nutritional value characteristics relate to growth and digestive balance parameters (Table I and Table II).

Table 1: Growth Parameters

\begin{tabular}{|c|c|}
\hline Parameters of growth & Formula \\
\hline Body Weight Gain (BWG) & BWG $(\mathrm{g} / \mathrm{d})=[$ Final Weight $(\mathrm{g})$ - Initial Weight $(\mathrm{g})] / 21$ \\
\hline Ingested Food (IF) & IF $(\mathrm{g} / \mathrm{d})=[$ Food served $(\mathrm{g})-$ Food refused $(\mathrm{g})] / 21$ \\
\hline Moisture Content (MC) & $\begin{array}{l}\text { MC }(\%)=[(\text { Fresh mass }(\mathrm{g})-\text { Dry mass }(\mathrm{g})) / \text { Fresh mass } \\
(\mathrm{g})] \times 100\end{array}$ \\
\hline Dry Matter content (DM) & $\mathrm{DM}(\%)=100-\mathrm{MC}$ \\
\hline Dry Matter Intake (DMI) & DMI $(\mathrm{g} / \mathrm{d})=$ Ingested Food $(\mathrm{g}) \times \mathrm{DM} / 21$ \\
\hline Ingested Total Starch (ITS) & ITS $(\mathrm{g} / \mathrm{d})=$ DMI $(\mathrm{g}) \times$ Diet Starch Content \\
\hline Ingested Total Protein (ITP) & ITP $(\mathrm{g} / \mathrm{d})=$ DMI $(\mathrm{g}) \times$ Diet Protein Content \\
\hline Ingested Sugar (IS) & IS $(\mathrm{g} / \mathrm{d})=$ DMI $(\mathrm{g}) \times$ Diet Sugar Content \\
\hline Food Efficiency Coefficient (FEC) & $\mathrm{FEC}=\mathrm{BWG}(\mathrm{g}) / \mathrm{DMI}(\mathrm{g})$ \\
\hline Protein Efficiency Coefficient (PEC) & $\mathrm{PEC}=\mathrm{BWG}(\mathrm{g}) / \mathrm{ITP}(\mathrm{g})$ \\
\hline Starch Efficiency Coefficient (SEC) & $\mathrm{SEC}=\mathrm{BWG}(\mathrm{g}) / \mathrm{ITS}(\mathrm{g})$ \\
\hline
\end{tabular}

Table 2: Digestive Balance Parameters

\begin{tabular}{|l|l|}
\hline \multicolumn{1}{|c|}{ Settings of Digestive Balance } & \multicolumn{1}{c|}{ Formula } \\
\hline Digestibility of dry matter (DDM) & $(\mathrm{DDM})(\%)=[\mathrm{DMI}(\mathrm{g})-\mathrm{DMF}(\mathrm{g})] \times 100 / \mathrm{DMI}(\mathrm{g})$ \\
\hline Digestibility of sugar $($ sucrose $)$ & Digestibility of sugar $(\%)=[\mathrm{IS}(\mathrm{g})-\mathrm{SF}(\mathrm{g})] \times 100 / \mathrm{IS}(\mathrm{g})$ \\
\hline Digestibility of Starch $(\mathrm{DS})$ & $(\mathrm{DS})(\%)=[\mathrm{ITS}(\mathrm{g})-\mathrm{SCF}(\mathrm{g})] \times 100(\mathrm{~g}) /$ ITS $(\mathrm{g})$ \\
\hline
\end{tabular}




\section{Results}

\section{Evolution of Rat Growth}

Rats have grown steadily throughout experimentation time. Rats fed cassava diets have a much higher growth rate. This growth is more pronounced in rats fed attoukpou and placali diets. Rats fed on sugar and potato diets have much lower growth (Figure 1).

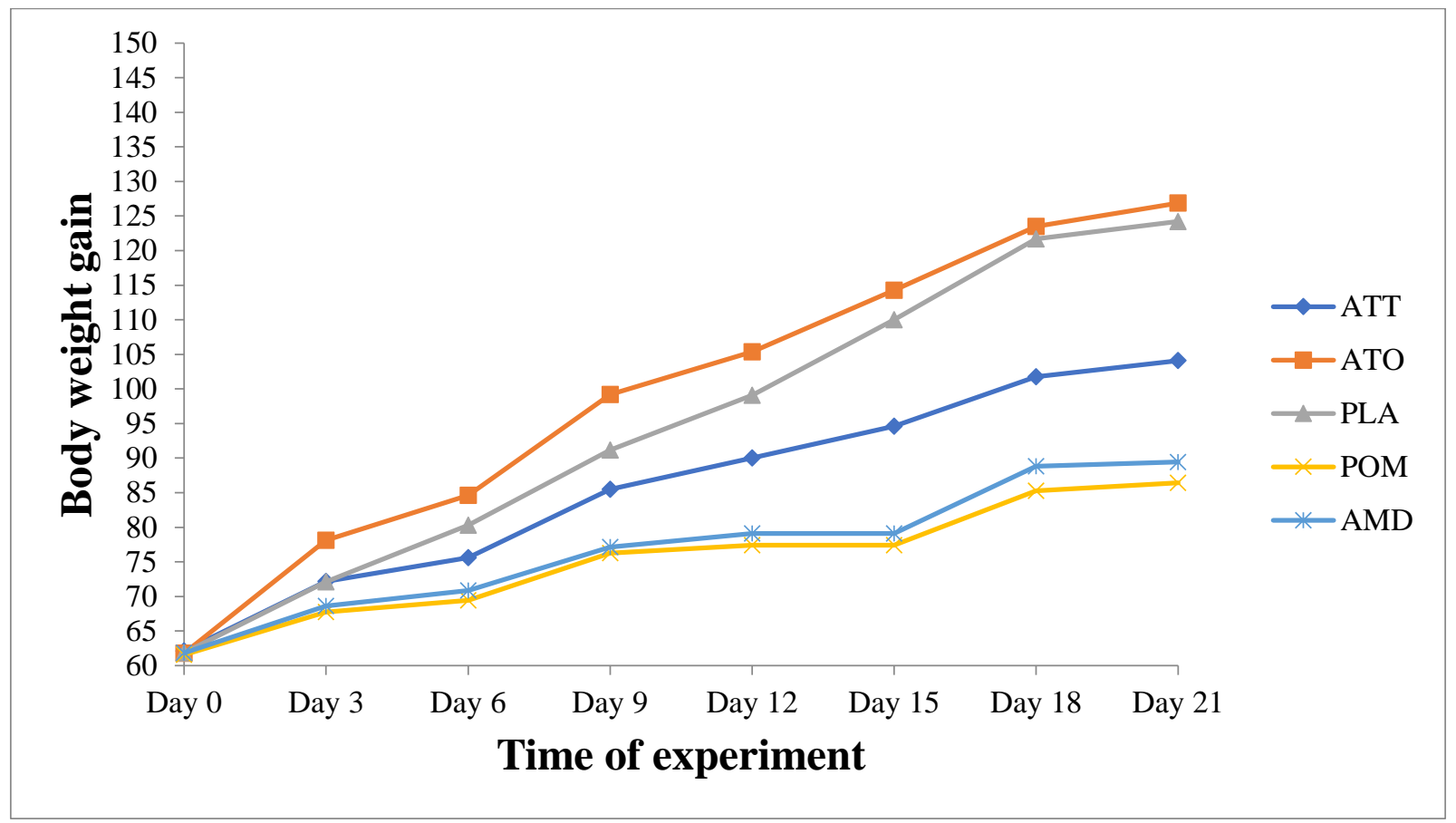

Figure 1: Evolution of body weight

ATT: diet based on attiéké; ATO: diet based on attoukpou; PLA: diet based on placali; POM: diet based on potato starch; AMD: diet without starch (sucrose-based diet); $(n=7)$.

\section{Nutritional Characteristics and Digestive Balance}

The following nutrient parameters, Body Weight Gain (BWG), Ingested Food (IF), Dry Matter Intake (DMI), Total Ingested Starch (TIS), Total Ingested Protein (TIP), Food Efficiency Coefficient (FEC), Protein Efficiency Coefficient (PEC), Starch Efficiency Coefficient (SEC), are reported in Table II. Digestive balance consisted in determining digestibility of starch (DS), digestibility of sucrose and digestibility of dry matter (DDM). Values of balance sheets have been reported in Table III.

Table 2: Average values of nutritional characteristics

\begin{tabular}{|c|c|c|c|c|c|}
\hline \multirow{2}{*}{ Settings } & \multicolumn{5}{|c|}{ Diets } \\
\cline { 2 - 6 } & $\begin{array}{c}\text { ATT } \\
(\mathbf{n = 6})\end{array}$ & $\begin{array}{c}\text { ATO } \\
(\mathbf{n = 6})\end{array}$ & $\begin{array}{c}\text { PLA } \\
(\mathbf{n = 6})\end{array}$ & $\begin{array}{c}\text { POM } \\
(\mathbf{n = 6})\end{array}$ & $\begin{array}{c}\text { AMD } \\
(\mathbf{n = 6})\end{array}$ \\
\hline Rat initial weight $(\mathrm{g})$ & $62,12 \pm 3,06^{\mathrm{a}}$ & $61,77 \pm 2,09^{\mathrm{a}}$ & $61,85 \pm 2,52^{\mathrm{a}}$ & $61,55 \pm 4,80^{\mathrm{a}}$ & $61,82 \pm 4,97^{\mathrm{a}}$ \\
\hline Rat initial weight $(\mathrm{g})$ & $104,08 \pm 5,14^{\mathrm{a}}$ & $126,87 \pm 6,69^{\mathrm{b}}$ & $124,21 \pm 5,63^{\mathrm{b}}$ & $86,42 \pm 5,90^{\mathrm{c}}$ & $89,44 \pm 6,34^{\mathrm{c}}$ \\
\hline
\end{tabular}




\begin{tabular}{|l|l|l|l|l|l|}
\hline $\begin{array}{l}\text { Body weight gain } \\
\text { (BWG) (g/d / rat) }\end{array}$ & $2,09 \pm 0,22^{\mathrm{a}}$ & $3,25 \pm 0,44^{\mathrm{b}}$ & $3,08 \pm 0,37^{\mathrm{b}}$ & $1,24 \pm 0,33^{\mathrm{c}}$ & $1,38 \pm 0,30^{\mathrm{c}}$ \\
\hline $\begin{array}{l}\text { Ingested food (IF) (g / } \\
\mathrm{d} / \text { rat) }\end{array}$ & $23,84 \pm 2,77^{\mathrm{a}}$ & $24,53 \pm 3,29^{\mathrm{a}}$ & $24,97 \pm 2,89^{\mathrm{a}}$ & $14,92 \pm 1,42^{\mathrm{b}}$ & $10,69 \pm 2,21^{\mathrm{c}}$ \\
\hline $\begin{array}{l}\text { Dry Matter Intake } \\
\text { (DMI) (g / d / rat) }\end{array}$ & $11,53 \pm 1,34^{\mathrm{a}}$ & $11,84 \pm 1,58^{\mathrm{a}}$ & $12,07 \pm 1,40^{\mathrm{a}}$ & $9,27 \pm 0,88^{\mathrm{b}}$ & $8,55 \pm 1,77^{\mathrm{b}}$ \\
\hline $\begin{array}{l}\text { Ingested Total Protein } \\
\text { (ITP) (g / d / rat) }\end{array}$ & $2,07 \pm 4,83^{\mathrm{a}}$ & $2,13 \pm 5,72^{\mathrm{a}}$ & $2,17 \pm 5,04^{\mathrm{a}}$ & $1,67 \pm 3,19^{\mathrm{b}}$ & $1,53 \pm 6,37^{\mathrm{b}}$ \\
\hline $\begin{array}{l}\text { Protein Efficiency } \\
\text { Coefficient (PEC) }\end{array}$ & $1,02 \pm 0,11^{\mathrm{a}}$ & $1,55 \pm 0,22^{\mathrm{b}}$ & $1,43 \pm 0,16^{\mathrm{b}}$ & $0,75 \pm 0,06^{\mathrm{d}}$ & $0,92 \pm 0,18^{\mathrm{c}}$ \\
\hline $\begin{array}{l}\text { Food Efficiency } \\
\text { Coefficient (FEC) }\end{array}$ & $0,19 \pm 0,02^{\mathrm{a}}$ & $0,27 \pm 0,03^{\mathrm{b}}$ & $0,25 \pm 0,02^{\mathrm{b}}$ & $0,13 \pm 0,01^{\mathrm{d}}$ & $0,16 \pm 0,03^{\mathrm{c}}$ \\
\hline $\begin{array}{l}\text { Ingested total starch } \\
\text { (ITS) (g / d rat) }\end{array}$ & $5,19 \pm 0,60^{\mathrm{a}}$ & $5,33 \pm 0,71^{\mathrm{a}}$ & $5,43 \pm 0,63^{\mathrm{a}}$ & $4,17 \pm 0,39^{\mathrm{b}}$ & - \\
\hline $\begin{array}{l}\text { Starch Efficiency } \\
\text { Coefficient (SEC) }\end{array}$ & $0,40 \pm 0,04^{\mathrm{a}}$ & $0,62 \pm 0,08^{\mathrm{b}}$ & $0,57 \pm 0,06^{\mathrm{b}}$ & $0,30 \pm 0,02^{\mathrm{c}}$ & - \\
\hline
\end{tabular}

n: Number of rats per diets. Variance analysis followed by Newman-Keuls test. On the same line, averages followed by different letters are significantly different $(\mathrm{p} \leq 0.05)$. ATT: diet based on attiéké. ATO: diet based on attoukpou, PLA: diet based on placali; POM: diet based on potato starch; AMD: diet without starch (sucrose-based diet).

Table 3: Average value of characteristics of digestive balance

\begin{tabular}{|l|l|l|l|l|l|}
\hline \multicolumn{1}{|c|}{ Settings } & \multicolumn{5}{|c|}{ Diets } \\
\cline { 2 - 6 } & \multicolumn{1}{|c|}{$\begin{array}{c}\text { ATT } \\
(\mathbf{n = 6})\end{array}$} & $\begin{array}{c}\text { ATO } \\
(\mathbf{n = 6})\end{array}$ & $\begin{array}{c}\text { PLA } \\
(\mathbf{n = 6})\end{array}$ & \multicolumn{1}{c|}{$\begin{array}{c}\text { POM } \\
(\mathbf{n = 6})\end{array}$} & \multicolumn{1}{|c|}{$\begin{array}{c}\text { AMD } \\
(\mathbf{n = 6})\end{array}$} \\
\hline $\begin{array}{l}\text { Digestive utilization } \\
\text { coefficient of starch or } \\
\text { digestibility of starch } \\
\text { (DS) }\end{array}$ & $95,57 \pm 1,11^{\mathrm{a}}$ & $97,69 \pm 1,23^{\mathrm{b}}$ & $99,02 \pm 0,97^{\mathrm{c}}$ & $76,96 \pm 5,15$ & - \\
\hline d & & & & & \\
\hline Digestibility of sucrose & - & - & - & - & $99,78 \pm 0,06$ \\
\hline $\begin{array}{l}\text { Digestive Utilization } \\
\text { Coefficient of dry } \\
\text { matter (DDM) }\end{array}$ & $88,72 \pm 1,27^{\mathrm{b}}$ & $91,02 \pm 1,24^{\mathrm{c}}$ & $92,18 \pm 0,70^{\mathrm{c}}$ & $78,85 \pm 1,72^{\mathrm{d}}$ & $94,76 \pm 1,04^{\mathrm{a}}$ \\
\hline
\end{tabular}

n: Number of rats per diets. Variance analysis followed by Newman-Keuls test. On the same line, averages followed by different letters are significantly different $(\mathrm{p} \leq 0.05)$. ATT: diet based on attiéké. ATO: diet based on attoukpou, PLA: diet based on placali; POM: diet based on potato starch; AMD: diet without starch (sucrose-based diet).

\section{Discussion}

During animal experiment, diets distributed to rats favored their growth. This is evidenced by daily weight gains observed in animals of the five carbohydrate diets. These results corroborate those observed by Kouakou et al. (2012), whose studies have centred on rats consuming plantain-based carbohydrate diets for 12 days. Weight gain of experimental animals bears witness to the good use of diet proteins during organs development (Bouaffou et al., 2007, Pargot et al., 1983) and the good use of energy nutrients during growth of adipose tissue. Indeed, according to Faust et al. (2017), a large increase in number of adipocytes can be produced in rats of various strains, by consumption of a high-fat diet or high-carbohydrate diet. 
In addition, cassava diets (ATT, ATO and PLA) resulted in significantly higher rat growth than sucrose (AMD) and potato (POM) diets. The low growth of rats fed sucrose-based diets is consistent with work of Gatineau (2017) that a sucrose-rich diet (50\% fructose) impairs the stimulation of postprandial protein synthesis in rats, thus slowing growth. In humans, Lowndes et al. (2014) showed that fructose, integrated in a eucaloric diet and consumed with glucose does not seem to favor weight gain. The low growth of rats consuming potato diet during our experiment, corroborates the work of Leroy et al. (1952) in pigs. This implies that potato flour and sucrose do not facilitate a significant growth of rats, unlike cassava-based foods that lead to remarkable growth.

In contrast, among rats fed cassava-based diets, those fed attoukpou and placali diets had significantly higher growth than rats consuming attiéké diet. This is explained by differences observed in processes for preparing these dishes (attiéké, attoukpou and placali). In the case of attiéké, relatively low temperature of the drying process, before steam-cooking, leads to a partial gelatinization which changes the conformation of the starch making it more resistant during digestion (Tako et al., 2014).

Based on weight gains and food consumption, food efficiency coefficients provide a better assess to the performance of use of food intake. The food efficiency coefficients (CEA) of ATO, PLA and ATT (cassava dishes) are significantly higher than those of potato and sucrose diets. Compared to the work of Digbeu (2010) and Kouakou et al. (2012), the feed efficiency coefficients of cassava-based diets in this study are higher than those of unfermented lokpa' cassava flour, unfermented bètè bètè yam flour diet reported by Digbeu (2010), and hybrid banana fruit prepared by CNRA (Kouakou et al., 2012). At equal consumption, cassava-based diets are therefore more effectively used in rat growth.

However, efficacy of attoukpou and placali-based foods is greater than that of the attiéké-based diet, although there is no significant difference between the amounts of dry matter and starch ingested. Indeed, each technological treatment involves physical transformations of starch grains up to a depolymerization. Attiéké starch compared to other cassava dishes is partially gelatinized during the culinary treatments and therefore more resistant (Champ et al., 1993).

The five diets used are iso-protein and iso-energetic. Proteins used in diets come mainly from delipidated soya flour. In these different diets, only varies the source of carbohydrate energy, source of protein is the same. However, protein efficiency of ATO and PLA regimes is significantly higher than that of ATT and AMD regimes. POM diet has the lowest protein efficiency. It may therefore be apparent from this study that the carbohydrate energy source influences protein utilization. These observations corroborate those of Desmoulin et al. (1967) and Szylit et al. (1977). Indeed, the work of Szylit et al. (1977) clearly show that protein efficiency may vary according to the starch source of the diet in the cockerels. According to Desmoulin et al. (1967), protein efficiency is higher with starch-rich diets, compared to high-sucrose diets, at low protein levels. Several studies can be invoked to explain the different effects of carbohydrates on protein efficiency. Carbohydrates can act on the speed of gastrointestinal transit or on mechanisms of digestion and absorption. On the other hand, the digestive environment and in particular the microflora are modified. Thus, starch favors microbial synthesis more than sucrose (Desmoulin et al., 1967). In sum, carbohydrates provided by cassava-diets (attoukpou and placali) are much more 
conducive to use of proteins, compared to carbohydrates from attiéké and sucrose. Potato starch allows a small use of proteins.

The coefficients of digestive use of starch or in vivo digestibility of starch from cassava-based diets have values greater than $95 \%$, with significantly greater digestibility in ATO and especially PLA diets. These values confirm the results of Adrian et al. (1991) who showed that digestibility of starch is usually greater than $95 \%$. Zoumenou (1994) has also shown that starch digestibility of cassava-based diets (foutou, traditional and improved placali, kokondé) and cornstarch is greater than 95\%. In addition, Kouakou et al. (2012) have shown that starch digestibility levels of plantainbased and fruit-based hybrids of the Orishele variety are very high. However, 30\% of cayenerasis yam starch are nondigestible (Szylit et al., 1977). According to Szylit et al. (1977), physicochemical transformations of starch have an impact on its efficiency and its digestibility. Starch modifications that influence its digestibility could be in terms of parameters such as grain size, crystal organization, amylose content and amylase sensitivity. Structure of starch depends on the botanical origin of the starch considered and the technological treatments it has previously undergone (Favier, 1969). Thus, during the culinary treatments, starches of attoukpou and placali undergo significant gelatinization compared to attiéké's starch whose gelatinization is partial. This phenomenon of gelatinization more pronounced in the case of placali and attoukpou (because of the stronger hydration of the starch before cooking), makes the starch more digestible. Under action of high temperature (during cooking) and high water content, the physical and granular structure of the starch is modified. These two factors irreversibly disrupt the crystalline structure of starch, making it readily hydrolyzable by amylases (Kouassi et al., 2009; Cândido et al., 2013). In addition, according to Favier (1969), fermentation promotes digestibility. It initiates partial degradation of polysaccharides into simpler fragments. As a result, by the multi-chain attack mechanism of $\alpha$-amylase, the rate of amylolysis increases with the increase of fragments that can be attacked more rapidly by the enzyme, which facilitates digestion (Zoumenou, 1994, Kouakou et al., 2012).

Potato-based diet has significantly lower starch digestibility than cassava-based diets. Perisse et al. (1956) and Favier (1969) showed that cassava starch was more readily hydrolysable after fermentation, and after the slight heating it undergoes, during the preparation of gari. Another reason would be botanical difference. According to Favier (1969), it appears that starches of South Cameroon's food plants meet the Brown and Heron classification, which situates the digestion of cassava and plantain above that of potato and taro.

The digestibility of sucrose in AMD diet is almost complete. These results corroborate those of Cunningham et al. (1963) and Champ et al. (1993). According to these authors, the digestibility of sucrose in pigs varies initially at the ileal level from 72 to $95 \%$ depending on the amount ingested (Cunningham et al., 1963). Disaccharides (sucrose), which are not digested in the small intestine by the animal's enzymes, are then hydrolysed and absorbed in the large intestine (Champ et al., 1993).

\section{Conclusion}

Finally, cassava-based foods (attiéké, attoukpou and placali), potato starch and sucrose resulted in different nutritional performances in wistar strain rats. Cassava based-diets (attiéké, attoukpou and 
placali) have resulted in very good growth of rats, the efficiency of these foods is better, the starch of cassava dishes has a digestibility greater than $95 \%$. However, the important culinary treatments that starch of attiéké undergoes, reduce these nutritional performances compared to attoukpou and placali. Cassava-based foods, mainly attoukpou and placali, favored protein utilization in rat growth. Diets based on potato starch and sucrose have the lowest feed efficiency. Digestibility of potato starch is lower than that of cassava starch. Sucrose, on the other hand, has almost complete digestibility but a very low growth performance in rats. Consumption of Cassava dishes may therefore dampen undernourishment. However, to determine the effects of these dishes on the state of health of animals, a physiological study must be undertaken to check the condition of organs and blood parameters.

\section{References}

[1] Adrian J., Rahache M. \& Fragne R. (1991). “Technique D’analyse Nutritionnelle. In: Principes Des Techniques D’analyses.” Ed. Lavoisier Tec Et Doc, Paris (France), Pp: 451-478.

[2] Apa. (2017). "Agence De Presse Africaine. Donnees Publiees Par La Direction De La Production Et De La Securite Alimentaire Du Ministere Ivoirien De L'agriculture Et Du Developpement Rural.” Http://Www.Agrici.Net/2017/06/06/Cote-Divoire-A-Produit-454-Millions-De-TonnesDe-Manioc-2016/. Visited On 27 September 2017.

[3] Bouafou K. G. M. (2007). "Etude De La Production D'asticots a Partir D'ordures Menageres Et De La Valeur Nutritionnelle De La Farine D'asticots Seches (F. A. S.) Chez Le Rat En Croissance." Thèse De Doctorat De L'université Felix Houphouët-Boigny, Abidjan, Côte D'ivoire, 146 P.

[4] Cândido F. G., Pereira E. V. \& Alfenas R. C. G. (2013). "Use of The Glycemic Index in Nutrition Education.” Nutr. Rev., 26: 89-96. Http://Dx.Doi.Org/10.1590/S1415-52732013000100009

[5] Champ M. \& Colonna P. (1993). "Importance De L'endommagement De L'amidon Dans Les Aliments Pour Animaux." Inra Prod. Anim., 6(3): 185-198. Https://Hal.Archives-Ouvertes.Fr/Hal00896053

[6] Cunningham H. M., Friend D. W. \& Nicholson J. W. G. (1963). "Observations on Digestion In The Pig Using Re-Entrant Intestinal Fistula.” Can. J. Anim. Sci., 43: 215-225.

[7] Desmoulin B., Lecourtier M. \& Peiniau P. (1967). "Influence De L'amidon De Maïs Et Du Saccharose Sur La Consommation Des Regimes Selon Le Taux Azote: Consequences Sur La Composition Corporelle Du Rat Blanc." Ann. Biol. Anim. Bioch. Biophys. 7(2): 163-172. Https://Hal.Archives-Ouvertes.Fr/Hal-00896370

[8] Digbeu D. Y. (2010). "Inventaires Et Carateristiques Nutritionnelles Des Ignames Cultivees Dans Les Zones De Production De La Cote D'ivoire: Formulation D'aliment De Complement A Base Dioscorea Alata Et Dioscorea Cayenensis-Rotundata." Thèse De Doctorat De L'université D’abobo-Adjamé, Abidjan, Côte D'ivoire, 155 P.

[9] Fao 2015. "Vue D'ensemble Regionale De L'insecurite Alimentaire En Afrique: Des Perspectives Plus Favorables Que Jamais.” Fao Ed., Ghana, Accra, 39p.

[10] Fao (2013). "Bases De Donnees Statistiques Du Fonds Des Nations Unies Pour L'alimentation Et L'agriculture." Www.Faostat.Org. Visited On 11 March 2017.

[11] Faust M. I., Johnson R. P., Stern S. J. \& Hirsch J. (2017). "Diet-Induced Adipocyte Number Increase in Adult Rats: A New Model of Obesity." Am. J. Physiol., 235(3): 279-286.

[12] Favier J-C. (1969). "Etude De La Digestibilite "In Vitro" De L'amidon De Diverses Plantes Alimentaires Du Sud-Cameroun: Influence Des Transformations Technologiques Sur L'amidon De Manioc.” Industr. Alim. Agr. 86 (1): 8 - 13.

[13] Garcin H., Higueret P. \& Amoikon K. (1984). "Effect of Large Dose of Retinol or Retinoid Acid On Thyroid Hormones in The Rats." Ann. Nutr. Metab. 28: 92-100.

Https://Www.Ncbi.Nlm.Nih.Gov/Pubmed/6696397 
[14] Gatineau E. (2017). “Impact D’un Regime Riche En Saccharose Sur La Sarcopenie Chez Le Rat Age - Consequences Metaboliques Au Niveau Hepatique Et Cerebral - Effets Preventifs D’un Melange De Micronutriments.” Thèse De Doctorat, Auverge, France. 420 P.

[15] Kouakou K. K. A., Coulibaly S., Atchibri O-A. L., Kouamé G. \& Meité A. (2012). "Evaluation Nutritionnelle Comparative Des Fruits De Trois Hybrides De Bananiers (Crbp 39, Fhia 17 Et Fhia 21) Avec Ceux De La Variete Orishele.” Tropicultura, 30(1): 49-54.

[16] Kouassi K. N., Tiahou G. G, Abodo F. R. J., Camara Cisse M. \& Amani N. G. (2009). "Influence of the Variety and Cooking Method on Glycemic Index of Yam," Pakistan Journal Of Nutrition, 8(7): 993-999. Https://Scialert.Net/Abstract/?Doi=Pjn.2009.993.999

[17] Leroy A. M., Zelter S. \& Février R. (1952). "L'utilisation De La Pomme De Terre Pour L'alimentation Des Animaux Domestiques. Ann. Zootech., Inra/Edp Sciences," 1(1): 87-145. Https://Hal.Archives-Ouvertes.Fr/Hal-00886562/Document

[18] Lowndes J., Sinnett S., Pardo S., Nguyen V. T., Melanson K. J., Yu Z., Lowther B. E. \& Rippe J. M. (2014). "The Effect of Normally Consumed Amounts of Sucrose or High Fructose Corn Syrup On Lipid Profiles, Body Composition And Related Parameters In Overweight/Obese Subjects.” Nutrients, 6(3): 1128-44. Doi: 10.3390/Nu6031128.

[19] Pargot J., Bres P. \& Lerlerq L. (1983). "Manuel D'aviculture En Zone Tropicale 2eme De La Serie Manuel Et Precis D'elevage Realise Par L'institut D'elevage Et De Medecine Veterinaire Des Pays Tropicaux 10 Rue Pierre Curie A Maison Alfort Publie Par Le Ministere De La Cooperation," France, $185 \mathrm{P}$.

[20] Pellet P. L. \& Young V. R. (1980). "Nutritional Evaluation of Protein Foods.” Food, 26(3): 323323.

[21] Perrin A., Ricau P., Rabany C. (2015). "Etude De La Filiere Manioc En Cote D’ivoire.” Projet « Promotion Et Commercialisation De La Banane Plantain Et Du Manioc En Côte D'ivoire » Financé Par Le Comité Français Pour La Solidarité Internationale (Cfsi). Perrin Audrey, Ricau Pierre, Rabany Cédric De Rongead Ed., France, 87p.

[22] Perisse J., Adrian J. \& Jacquot R. (1956). "Etude $<<$ In Vitro $>>$ Et $<<$ In Vivo $>>$ De La Digestibilite Du Manioc Sous Differentes Formes : Farine Entiere, Farine Blutee, Fecule Et Gari. Ann. Nutrition Et Alimentation," 10(2): 13-21. Https://Core.Ac.Uk/Download/Pdf/39888628.Pdf

[23] Szylit O., Borgida L. P., Bewa H., Charbonnière R. \& Delort-Laval J. (1977). "Valeur Nutritionnelle Pour Le Poulet En Croissance, De Cinq Amylaces Tropicaux En Relation Avec Quelques Caracteristiques Physico-Chimiques De Leur Amidon.” Ann. Zootech., 26(4): 547-563. Https://Hal.Archives-Ouvertes.Fr/Hal-00887777/Document

[24] Tako M., Tamaki Y., Teruya T. \& Takeda Y. (2014). "The Principles of Starch Gelatinization and Retrogradation.” Food and Nutrition Sciences (Fns). 5: 280-291.

Https://File.Scirp.Org/Pdf/Fns_2014012210240970.Pdf

[25] Yao K. J., Koffi R. A. \& Aboua F. (2006). "Composition De La Poudre D’attieke Deshydratee." Trop. Sci., 46(4): 224-226.

[26] Yéboué K. H., Amoikon K. E., Kouamé K. G. \& Kati-Coulibaly S. (2017). "Valeur Nutritive Et Proprietes Organoleptiques De L'attieke, De L'attoukpou Et Du Placali, Trois Mets a Base De Manioc, Couramment Consommes En Cote D'ivoire." J. Appl. Biosci. 113: 1118411191.M.Elewa.Org/Journals/Wp-Content/Uploads/2017/05/7.Yeboue-Abstract-Vol.113.Pdf

[27] Zoumenou M. R. B. V. (1994). "Etudes Physico-Chimique Et Nutritionnelle De Quelques Preparations Alimentaires A Base De Manioc, (Manihot Esculenta, Crantz)." Thèse De 3ième Cycle De L'université Felix Houphouët-Boigny, Abidjan, Côte D’ivoire, 117p.

*Corresponding author.

E-mail address: yeboue2@yahoo.fr 